\title{
GEOCHEMICAL CHARACTERIZATION OF SERPENTINITES AT CABO ORTEGAL, NORTHWESTERN SPAIN
}

\author{
M. Dolores PEREIRA ${ }^{\S}$, Mercedes PEINADO, Jose ANTonio BLANCO ANd Mariano YenES \\ Depto. Geología, Plaza de la Merced s/n, Universidad de Salamanca, E-37008 Salamanca, Spain
}

\begin{abstract}
Cabo Ortegal is one of the major ultramafic complexes outcropping in Iberia. Most rocks are variably serpentinized, and the characteristics of the process can be traced through the composition of the rocks. The major and trace elements change in the different units of the complex. Together with the wide range of oxygen isotope values $\left(\delta^{18} \mathrm{O}\right.$ from 3.9 up to $6.6 \%$ ), these changes lead to the conclusion that several stages of serpentinization took place at Cabo Ortegal. Each stage is characterized by the composition of the fluid that produced the serpentinization. Seawater does not have to be the main fluid in the process; an ultimate stage of serpentinization can mask the characteristics of a previous one.
\end{abstract}

Keywords: serpentinites, geochemistry, Cabo Ortegal, Spain.

SOMMAIRE

Le massif ultramafique de Cabo Ortegal est un des plus importants affleurant dans la péninsule ibérique. La plupart des roches sont plus ou moins serpentinisées, et on peut à tracer les caractéristiques du processus en étudiant la composition des roches. Les éléments majeurs et en traces changent selon l'unité du massif. Ces changements, de même que l'intervalle important des valeurs isotopiques de l'oxygène $\left(\delta^{18} \mathrm{O}\right.$ allant de 3.9 jusqu'à $6.6 \%$ ), mènent à la conclusion que plusieurs stades de serpentinisation ont imposé leurs effets à Cabo Ortegal. Chaque stade peut se distinguer par la composition de la phase fluide qui a produit la serpentinisation. L'eau de mer n'était pas nécéssairement le fluide principal à effectuer ces changements; un stade ultime de serpentinisation a pu masquer les caractéristiques d'un stade antécédant.

(Traduit par la Rédaction)

Mots-clés: serpentinites, géochimie, Cabo Ortegal, Espagne.

\section{INTRODUCTION}

The serpentinization of ultramafic rocks is a common process in which the original rock changes its mineralogical composition owing to the hydration of the original phases (Moody 1976, O’Hanley 1996). The chemical composition of serpentinites depends on the nature of the original rock and on the origin of the fluid phase (Pereira et al. 2003), and this origin will also be reflected in the newly formed serpentinegroup minerals. Our work has focused on one important ultramafic massif in northwestern Spain: Cabo Ortegal. We have used previous results on Ronda, in southeastern Spain (Pereira et al. 2003) for purposes of comparison. The Ronda massif is related to the Beni Bousera ultramafic complex, in Morocco, whereas Cabo
Ortegal is related to the Morais-Bragança complex, in neighboring Portugal. At Ronda, the emplacement of the peridotite slab by obduction during the Alpine orogeny caused partial melting of the Hercynian migmatites lying below. This anatexis produced a leucogranitic melt that intruded the peridotite as dikes, provoking a locally intense serpentinization of an already slightly serpentinized peridotite through the release of the orthomagmatic fluid (Pereira et al. 2003).

The Cabo Ortegal massif is part of a major ultramafic complex in northwestern Iberia, the Galicia complex in Spain and the Morais massif in Portugal. The ultramafic rocks are in large part allochthonous units, the stacking of nappes being the consequence of subduction and collision in the early phases of the Variscan orogeny in northwestern Iberia. Contacts

§_E-mail address: mdp@usal.es 
between the dislocated units are the result of ductile extensional detachments (Díaz García et al. 1999). The units are fragments of the lithospheric mantle at the base of the ophiolitic complexes. The various units within the allochthon (Upper and Inferior units, Peucat et al. 1990) have undergone several metamorphic events before being piled up and incorporated into the autochthonous terrane. Some authors have referred to the complex as representative of the "suprasubduction mantle" (Moreno et al. 2001). Our study area deals only with the uppermost unit, made up of three distinct massifs: Herbeira, Limo and Uzal, stacked one on top of the other, each with its own characteristics.

In this paper, we deal with the recognition of the different paths of serpentinization followed by the three peridotite massifs in the upper unit through a study of their mineralogy and geochemistry.

\section{Rock TYPES AND SAMPLES}

At Cabo Ortegal, we find mainly mafic and ultramafic rocks. The ultramafic rocks crop out at various structural levels within the complex. Several aspects have been studied, including petrology, structure, geochemistry, geochronology (e.g., Vogel 1967, Girardeau \& Gil Ibarguchi 1991, Santos Zalduegui et al. 1996, Gil Ibarguchi et al. 1999, Díaz García et al. 1999, Santos et al. 2002). The Herbeira, Limo and Uzal massifs, which comprise the upper allochthonous unit, equilibrated under eclogitic high-P granulite-facies conditions. Harzburgite, orthopyroxenite and dunite, the main lithologies, are fully described in Santos et al. (2002). The ultramafic rocks are generally characterized by a high degree of serpentinization, but where they are relatively unserpentinized, a harzburgite made up of orthopyroxene, olivine, tremolite, chlorite, spinel and magnetite can be seen. Some samples also contain clinopyroxene as an accessory mineral. In some places, layers of dunite are found. There is an important foliation in the rocks, locally highlighted by amphibole or fibrous serpentine or both (Díaz García et al. 1999), although the latter is commonly difficult to distinguish in intensely serpentinized rocks.

The samples studied in this work come from the three massifs mentioned, plotted in Figure 1. Uzal is structurally the lowest unit. Some of the rocks show a total transformation to low-temperature metamorphic minerals: serpentine minerals, carbonates, talc, chlorite and magnetite. They partially preserve remnants of the original chromian spinel. Limo is the intermediate unit; we were able to study only one sample of that body for this work. Herbeira, structurally the highest unit, has had a very complex metamorphic history: it first underwent eclogite-facies metamorphism, followed by partial hydration at successive stages under conditions of lower pressure and temperature. Consequently, the unit preserves its original anhydrous minerals to a variable degree. In addition, it contains evidence of the earliest metamorphic assemblages, with a minor amount of the low-temperature hydrous assemblages. These late

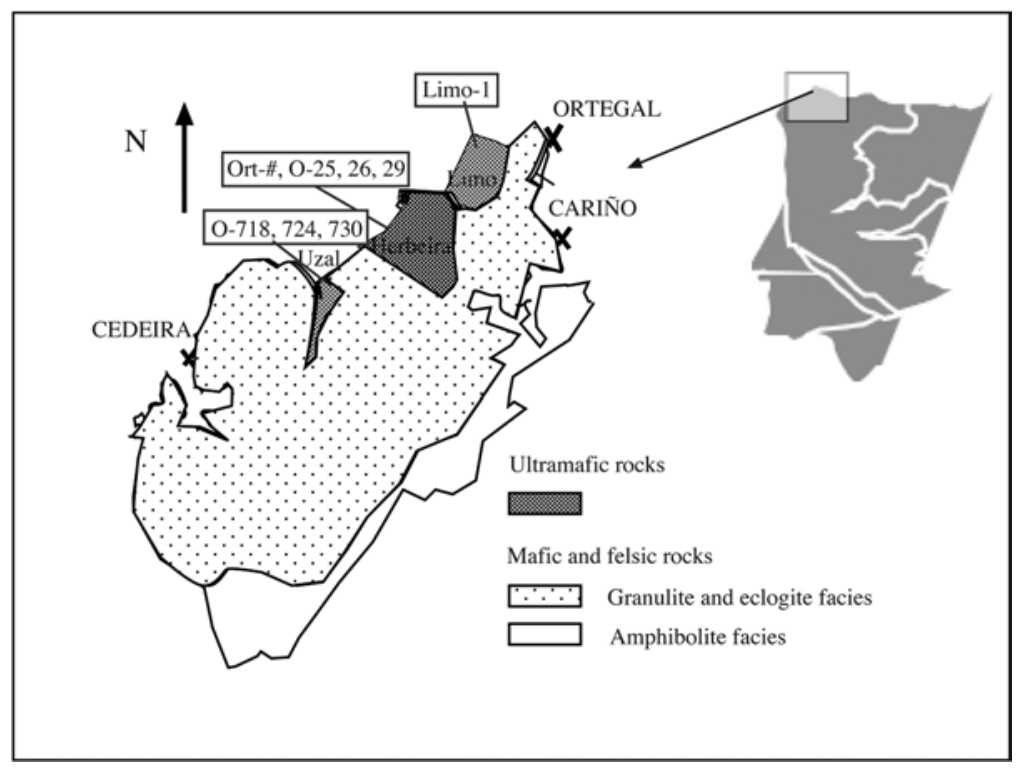

FIG. 1. Simplified scheme of the studied area. Samples belong to the Upper Unit of the Cabo Ortegal ultramafic complex. 
assemblages contain an amphibole, and formed during the subsequent stages of deformation, at the same time as the low-temperature assemblages typical of the lower units. The development of serpentinite during the last stage of thrusting occurred at temperatures below $550^{\circ} \mathrm{C}$ (uppermost limit for serpentinization in the presence of $\mathrm{H}_{2} \mathrm{O}$ : Moody 1976). But we have to take into account the possibility that the serpentinization process took place at different stages of hydrothermal activity, involving oceanic, hydrothermal and meteoric fluids. Some magmatic activity accompanied the earlier stages of thrusting (Díaz García et al. 1999), and magma-derived fluids also could be involved in the serpentinization process.

We took 12 samples from these units to characterize the degree of serpentinization of these rocks (Fig. 1). We deliberately avoided the fresh samples that have been very well studied by other authors (e.g., Santos et al. 2002, and references therein). The Herbeira massif has traditionally been exploited for refractory material for use in thermal power plants. The relatively fresh peridotite, locally called "dunite" by the miners, is made up of pyroxene, amphibole, remnants of olivine and spinel. In several areas, the outcrops are severely sheared (Fig. 2), providing fluid conduits for the local serpentinization of the original rock.

\section{Mineralogy}

Although a detailed petrographic study of the thin sections of the samples was done, we came up against serious difficulties when trying to identify the serpentinite-group minerals. X-ray diffraction must be used to distinguish the main components of serpentinization, but some accessory minerals are present in a quantity below $2 \%$, and might not be detected by diffraction. Where serpentinization affects the ultramafic rocks severely, only remnants of the original mineralogy can be distinguished (Pereira et al. 2007). Our samples are made up mainly of several serpentine phases, with remnants of olivine, orthopyroxene (presenting an exsolution texture), clinopyroxene and chromian spinel in various proportions. We have distinguished serpentine in a mesh texture, derived from the alteration of olivine, and "bastite", derived from the alteration of orthopyroxene (Wicks \& Whittaker 1977). At present, we only have recognized lizardite as the main serpentine phase, which agrees with the textures found (Wicks \& Whittaker 1977), but others could be identified in future investigations. As accessories, we find a green spinel and an amphibole. Some phases (e.g., the amphibole) may have crystallized during a metamorphic overprint. To get an approximation of the primary mineralogy, we have plotted the normative anhydrous composition on a modal diagram (Fig. 3). We conclude that most of the samples consist of harzburgite, one sample from Uzal (O-718) consists of dunite, and one from Herbeira (O-26), of lherzolite. The petrographic inferences are in concordance with the REE patterns shown in the geochemistry section.

We note a correlation between the original lithology and the degree of serpentinization: dunite (olivine $>90 \%$ ) appears as a completely serpentinized rock, whereas harzburgite (olivine 60\%, pyroxene $40 \%$ ) is less strongly serpentinized (D'Antonio \& Kristensen 2004). Most rocks have a porphyroclastic texture, except $\mathrm{O}-718$, which is finer grained and has a granoblastic texture. Fine-grained rocks allowed fluids to penetrate, and are more thoroughly serpentinized, whereas those with coarse-grained orthopyroxene are less strongly serpentinized.

\section{Geochemistry}

The samples were analyzed for major elements by X-ray fluorescence using a Philips PW 1404 spectrometer at the Universidad de Granada. Estimated errors are $\pm 1 \%$ for $\mathrm{Si}, \mathrm{Al}, \mathrm{Ti}, \mathrm{Fe}, \mathrm{Ca}, \mathrm{K}$ and $\mathrm{P}$, and $\pm 2 \%$ for $\mathrm{Na}, \mathrm{Mn}$ and $\mathrm{Mg}$. The same rocks were analyzed for trace elements by ICP-MS (except $\mathrm{Zr}$, by X-ray fluorescence), also at Universidad de Granada. Loss on ignition was measured at the Universidad de Salamanca. Whole-rock oxygen isotope analyses were carried out at the SURC Laboratories, East Kilbride, Scotland.

Although some authors have not found variations in the level of major and trace elements in serpentinized abyssal peridotites (Mével 2003, and references therein), a comparison of the geochemistry of the samples we examined leads us to the opposite conclusion, in agreement with the observations of Miyashiro et al. (1969).

\section{Major elements}

The samples show a shift in composition related to the progression of serpentinization. The greater the extent of serpentinization, the greater the impoverishment in some major elements (Table 1), as pointed out below.

Loss on ignition (LOI) results show that some of the relatively fresh samples from the Herbeira massif have a high content of $\mathrm{H}_{2} \mathrm{O}$ because of the presence of fine, serpentine-filled shears (Fig. 2). In general, we have taken this parameter to evaluate the degree of serpentinization of the rocks in this study, in view of the high $\mathrm{H}_{2} \mathrm{O}$ content in the serpentine structure $\left(\approx 13 \% \mathrm{H}_{2} \mathrm{O}\right)$, as was done by Kyser et al. (1999) and D'Antonio \& Kristensen (2004). We can thus distinguish two totally serpentinized samples (Ort-C and $\mathrm{O}-718$ ), whereas the majority of the samples are slightly serpentinized: Limo-1, Ort-A, Ort-B, Ort-D, Ort-S, O-25, O-724 and $\mathrm{O}-730$. The other two are relatively fresh rocks: O-26 and O-29 (see contents of $\mathrm{H}_{2} \mathrm{O}$ in Table 1).

We include the concentration of major elements in a relatively fresh sample of harzburgite from Herbeira, analyzed by Santos et al. (2002) (Table 1) to illustrate 
the deviation of the composition produced by serpentinization (Fig. 4). The levels of major elements, mainly $\mathrm{Ti}, \mathrm{Al}, \mathrm{Mn}, \mathrm{Na}$, but mostly $\mathrm{Ca}$, decrease in our samples. This pattern is made obvious in the most strongly serpentinized samples, and it has already been reported by other authors (Seyfried \& Dibble 1980). This reflects the total disappearance of the calcic pyroxene, which is destroyed by serpentinization. In fact, only the samples where clinopyroxene was detected presented an increase in $\mathrm{Ca}$. The same trend was observed for $\mathrm{K}_{2} \mathrm{O}$ in those samples fresher than the reference harzburgite.

\section{Trace elements}

We have found a general depletion in most of the 25 trace elements that we have sought (Table 2). A normal-

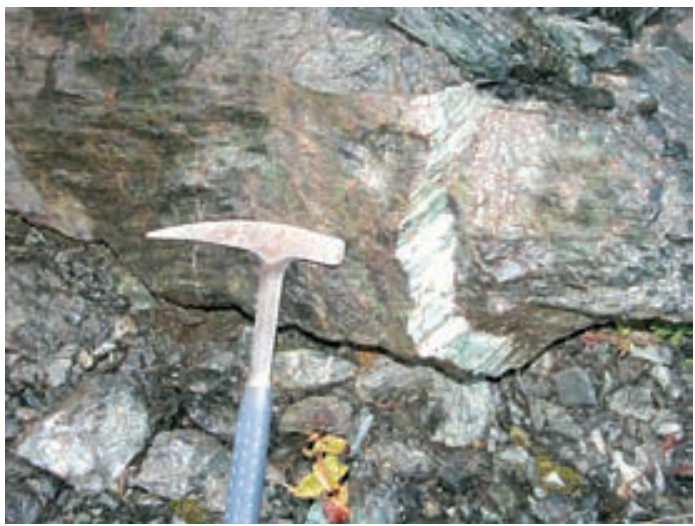

FIG. 2. Shears affecting the peridotite, filled with fibrous serpentine. ization to the same sample of relatively fresh harzburgite (Harzb-1) as used for the major elements has been adopted here. In this reference sample, Santos et al. (2002) described a low concentration of the HREE, a relative enrichment in the LREE, and a higher content of $\mathrm{Zr}, \mathrm{Nb}$ and $\mathrm{U}$ than in other ultramafic complexes like Ronda. Note that each rock unit, or even each sample, has its own peculiarities (Figs. 5a, b). In samples from the Herbeira unit (Fig. 5a), some samples are found to have a lower inferred degree of serpentinization (see content of $\mathrm{H}_{2} \mathrm{O}$ in Table 1), which explains the apparent enrichment of $\mathrm{Be}, \mathrm{Cr}, \mathrm{Cu}, \mathrm{Ta}, \mathrm{Mo}, \mathrm{Tl}, \mathrm{Pb}$ and Th. Many of the same elements are enriched in selected samples of the Uzal unit (Fig. 5b).

Relative levels of concentration of the rare-earth elements (Table 3 ) in the same samples are plotted

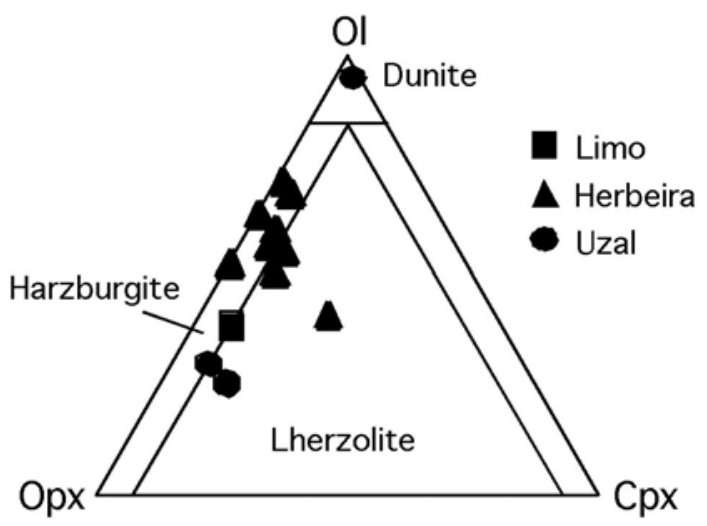

FIG. 3. Plot of anhydrous normative mineralogy of serpentinized peridotites.

TABLE 1. MAJOR-ELEMENT COMPOSITION OF SAMPLES OF SERPENTINIZED PERIDOTITE FROM CABO ORTEGAL

\begin{tabular}{|c|c|c|c|c|c|c|c|c|c|c|c|}
\hline Sample & $\mathrm{SiO}_{2}$ & $\mathrm{TiO}_{2}$ & $\mathrm{Al}_{2} \mathrm{O}_{3}$ & $\mathrm{FeO}$ & $\mathrm{MnO}$ & $\mathrm{MgO}$ & $\mathrm{CaO}$ & $\mathrm{Na}_{2} \mathrm{O}$ & $\mathrm{K}_{2} \mathrm{O}$ & LOI & Total \\
\hline ORT-A $w t \%$ & 41.73 & 0.04 & 2.48 & 8.41 & 0.10 & 38.31 & 2.05 & 0.06 & 0.00 & 8.44 & 101.62 \\
\hline ORT-B & 41.33 & 0.09 & 2.46 & 8.12 & 0.09 & 37.50 & 2.51 & 0.06 & 0.00 & 7.35 & 99.51 \\
\hline ORT-C & 38.99 & 0.00 & 1.06 & 8.06 & 0.05 & 38.09 & 0.11 & 0.06 & 0.00 & 13.46 & 99.88 \\
\hline ORT-D & 40.35 & 0.04 & 2.19 & 8.63 & 0.08 & 39.03 & 1.04 & 0.07 & 0.00 & 8.89 & 100.32 \\
\hline ORT-S & 40.63 & 0.03 & 1.11 & 9.37 & 0.11 & 41.38 & 0.69 & 0.07 & 0.01 & 7.16 & 100.56 \\
\hline 0.25 & 40.54 & 0.07 & 2.52 & 8.70 & 0.12 & 37.49 & 1.97 & 0.06 & 0.00 & 7.80 & 99.27 \\
\hline $0-26$ & 42.99 & 0.13 & 3.57 & 7.96 & 0.08 & 34.23 & 5.01 & 0.04 & 0.06 & 4.74 & 98.81 \\
\hline $0-29$ & 42.78 & 0.07 & 3.21 & 8.22 & 0.10 & 37.26 & 2.93 & 0.06 & 0.00 & 4.74 & 99.37 \\
\hline 0.724 & 34.83 & 0.01 & 0.19 & 11.37 & 0.48 & 40.09 & 0.02 & 0.07 & 0.01 & 14.46 & 101.23 \\
\hline 0.730 & 43.71 & 0.08 & 2.67 & 8.27 & 0.10 & 35.60 & 2.23 & 0.04 & 0.07 & 7.00 & 99.77 \\
\hline 0.718 & 43.75 & 0.08 & 3.44 & 7.78 & 0.09 & 33.83 & 3.37 & 0.05 & 0.03 & 7.64 & 100.06 \\
\hline Limo-1 & 42.02 & 0.07 & 3.07 & 8.15 & 0.10 & 34.90 & 2.49 & 0.05 & 0.02 & 9.10 & 99.97 \\
\hline Harzb-1 & 40.44 & 0.15 & 3.14 & 8.29 & 0.14 & 35.26 & 2.29 & 0.16 & 0.02 & 8.68 & 98.57 \\
\hline
\end{tabular}


TABLE 2. COMPOSITION OF THE SERPENTINIZED PERIDOTITE IN TERMS OF TRACE-ELEMENT CONCENTRATIONS (ppm)

\begin{tabular}{llllllllllllllll}
\hline Sample & $\mathrm{Li}$ & $\mathrm{Rb}$ & $\mathrm{Cs}$ & $\mathrm{Be}$ & $\mathrm{Sr}$ & $\mathrm{Ba}$ & $\mathrm{Sc}$ & $V$ & $\mathrm{Cr}$ & $\mathrm{Co}$ & $\mathrm{Ni}$ & $\mathrm{Cu}$ & $\mathrm{Zn}$ \\
\hline ORT-A & 1.36 & 0.07 & 0.05 & 0.51 & 12 & 7.05 & 15.39 & 59 & 2458 & 102 & 2398 & 14 & 22 \\
ORT-B & 1.36 & 0.27 & 0.05 & 0.58 & 12 & 9.47 & 17.05 & 64 & 2428 & 106 & 2433 & 19 & 20 \\
ORT-C & 0.44 & b.d.I. & 0.02 & 0.57 & 2.41 & 7.69 & 3.32 & 26 & 3272 & 119 & 2909 & 5.10 & 51 \\
ORT-D & 1.03 & 0.06 & 0.05 & 0.42 & 17 & 9.18 & 11.09 & 55 & 3646 & 106 & 2421 & 7.12 & 43 \\
ORT-S & 1.48 & 0.09 & 0.04 & 0.47 & 17 & 11 & 7.19 & 36 & 1804 & 132 & 2760 & 13 & 39 \\
O-25 & 1.64 & 0.17 & 0.04 & 0.41 & 10 & 14 & 15.33 & 63 & 1844 & 105 & 2431 & 23 & 22 \\
O-26 & 1.65 & 0.26 & 0.02 & 0.55 & 30 & 25 & 25.82 & 100 & 2910 & 102 & 2207 & 133 & 72 \\
O-29 & 1.51 & 0.22 & 0.01 & 0.38 & 20 & 21 & 18.33 & 78 & 2438 & 103 & 2378 & 23 & 22 \\
O-724 & 4.2 & 0.35 & 0.11 & 1.00 & 104 & 29 & 17.36 & 67 & 2300 & 100 & 2220 & b.d.I. 34 \\
O-730 & 2.33 & 0.56 & 0.15 & 0.49 & 30 & 44 & 21.50 & 92 & 2707 & 88 & 2030 & 2.49 & 19 \\
O-718 & 0.48 & b.d.I. & 0.01 & 0.69 & 1.97 & 1.30 & 3.97 & 8 & 234 & 151 & 1820 & 0.49 & 36 \\
Limo-1 & 2.93 & 0.66 & 0.18 & 0.39 & 47 & 29.20 & 17 & b.d.l. 2301 & 94 & 2241 & 31 & 28 \\
Harzb-1 & 2.14 & 1.16 & 0.05 & 0.17 & 28 & 64 & 15 & 67 & 1531 & 91 & 1852 & 34 & 38 \\
\hline
\end{tabular}

TABLE 2 (cont'd). COMPOSITION OF THE SERPENTINIZED PERIDOTITE IN TERMS OF TRACE-ELEMENT CONCENTRATIONS

\begin{tabular}{|c|c|c|c|c|c|c|c|c|c|c|c|c|}
\hline Sample & $\mathrm{Ga}$ & $Y$ & $\mathrm{Nb}$ & Ta & $\mathrm{Zr}$ & $\mathrm{Hf}$ & Mo & Sn & TI & $\mathrm{Pb}$ & $\mathrm{U}$ & Th \\
\hline ORT-A & 3.64 & 1.58 & 0.23 & 0.03 & 9.00 & 0.05 & 0.27 & b.d.t. & 0.01 & b.d.l. & 0.03 & b.d.l. \\
\hline ORT-B & 3.52 & 1.88 & 0.28 & 0.06 & 7.50 & 0.09 & 0.37 & b.d.l. & 0.01 & 0.26 & 0.03 & 0 \\
\hline ORT-C & 3.87 & 0.15 & 0.16 & 0.01 & 7.00 & 0.01 & 0.52 & b.d.l. & 0.01 & b.d.l. & 0.02 & b.d.l. \\
\hline ORT-D & 4.09 & 1.04 & 0.16 & 0.05 & 7.50 & 0.02 & 0.28 & 45 & 0.01 & 0.06 & 0.06 & 0 \\
\hline ORT-S & 3.50 & 0.61 & 0.65 & 0.22 & 9.30 & 0.04 & 3.54 & 54 & 0.01 & b.d.l. & 0.07 & 0.1 \\
\hline $0-25$ & 3.69 & 2.01 & 0.26 & 0.04 & 8.03 & 0.05 & 0.35 & b.d.t. & 0.01 & b.d.l. & 0.05 & 0 \\
\hline $0-26$ & 4.60 & 3.57 & 0.87 & 0.07 & 10 & 0.12 & 0.45 & 61 & 0.02 & 8.85 & 0.11 & 0.29 \\
\hline $0-29$ & 3.93 & 2.36 & 0.36 & 0.06 & 8.39 & 0.04 & 0.22 & 0.05 & 0.01 & b.d.l. & 0.10 & 0.25 \\
\hline $0-724$ & 4.68 & 3.30 & 1.28 & 0.08 & 8.30 & 0.18 & 0.30 & b.d.l. & 0.03 & 1.03 & 0.12 & 0.22 \\
\hline 0.730 & 4.53 & 2.82 & 0.81 & 0.21 & 13 & 0.09 & 0.34 & b.d.t. & 0.02 & b.d.l. & 0.14 & 0.25 \\
\hline 0.718 & 2.36 & 0.23 & 0.27 & 0.03 & 9.58 & 0.04 & 0.25 & b.d.t. & 0.02 & b.d.l. & 0.03 & b.d.l. \\
\hline Limo-1 & 4.16 & 2.38 & 0.43 & 0.06 & 7.39 & 0.07 & 0.29 & b.d.l. & 0.02 & b.d.l. & 0.10 & 0.1 \\
\hline Harzb-1 & 2.18 & 2.71 & 2.50 & 0.04 & 22 & 0.11 & 0.48 & 1.17 & 0.01 & 1.18 & 0.08 & 0.11 \\
\hline
\end{tabular}

Harzb-1 is a sample of harzburgite from Santos ef al. (2002). Results are quoted in ppm; b.d.l.: below detection limit. Analyses were made by the ICP-MS technique (except $Z r$, by X-ray fluorescence), at the Universidad de Granada.

in Figure 5c. The decrease in concentrations is more obvious in the case of these trace elements, in particular $\mathrm{Eu}$. If the choice of Harzb-1 as a reference material is appropriate, it seems clear that Eu was preferentially mobilized during serpentinization.

In Figure 6, we show profiles of the rare-earthelement concentrations plotted with respect to values in chondrite (Taylor \& McLennan 1985). Note that sample Limo-1 is the only one to have the profile expected according to the report of O'Hanley (1996). Many of the samples show a definite enrichment in the LREE. Sample O-718 is the most strongly depleted in $\mathrm{Ba}, \mathrm{Cu}, \mathrm{Zr}$ and all REE heavier than $\mathrm{Eu}$, and has the greatest proportion of serpentine. It is not likely that these elements were structurally bound in the precursor olivine, however. The implication is that in rocks showing an advanced degree of serpentinization, pyroxene-group minerals were also destroyed to account for the observed patterns of depletion. Sample O-26, a relatively fresh lherzolite, resembles the expected profile of clinopyroxene in ultramafic rocks (Mattielli et al. 1996).

\section{Oxygen isotopes}

We have characterized the $\delta^{18} \mathrm{O}$ values of the same samples in order to shed light on the source of the fluid phase that caused serpentinization (Table 4). The values range from 3.9 to $6.6 \%$. The two samples having a whole-rock value of $3.9 \%$ are the most intensely converted to serpentine. On the other hand, the two samples having the highest values of $\delta^{18} \mathrm{O}$ contain approximately $50 \%$ serpentine. Those samples containing the smallest proportion of serpentine $(\mathrm{O}-26$ and $\mathrm{O}-29)$ have values of 5.7 and $4.9 \%$. Values of $\delta^{18} \mathrm{O}$ reflect the mineralogy of the rocks, in particular, 

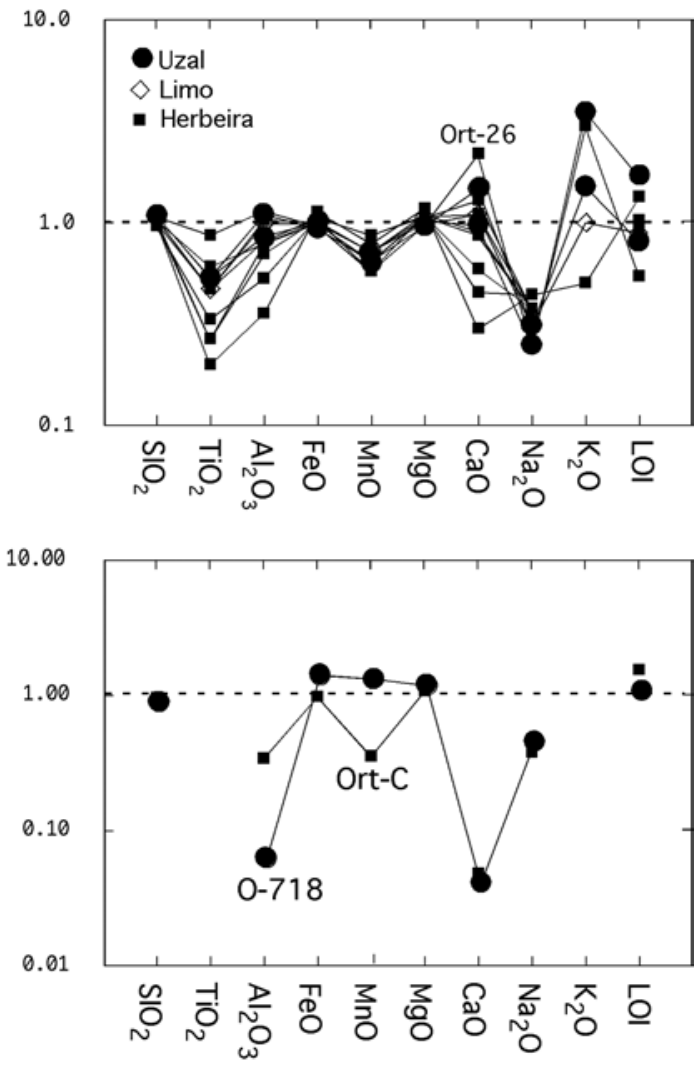

FIG. 4. Normalization of major-element concentrations to the harzburgite composition of Santos et al. (2002).

the proportion of serpentine, pyroxene-group minerals and magnetite.

The results just quoted point to additional variables, however. In particular, the temperature of last re-equilibration of the primary minerals in these peridotites and the source of the fluid phase will also be first-order variables. What makes any reconstruction challenging is the strong possibility that the samples chosen interacted more that once with a circulating hydrothermal fluid phase, and involved a variable source of the fluid.

The values observed have been plotted with reference to a "standard value" of 5.5\% (horizontal line in Fig. 7). Samples plotting above the reference line are considered to have interacted with a fluid phase of igneous derivation, whereas values below $5.5 \%$ o suggest a high-temperature interaction with a surface-derived fluid phase, including seawater (Mével 2003). It is interesting to note that most of the samples from the shallowest unit, Herbeira, are relatively deleted in ${ }^{18} \mathrm{O}$, whereas two of the three samples of the lowermost unit, Uzal, and the only sample of the Limo unit, from above the Uzal unit, are relatively enriched in ${ }^{18} \mathrm{O}$.

\section{DisCUSSION}

Most authors have not found that the conversion of peridotites to serpentinites causes major re-adjustments in the geochemistry of the rocks, except for the elements Cl, B, F and S (Mével 2003, and references therein). Our results, pertaining to representative samples taken from the uppermost part of the Cabo Ortegal massif, show that mineralogical changes led to important geochemical modifications. As a general statement, samples from the lower two units of the three sampled are significantly modified by interaction with aqueous fluid emanating from a magmatic source; in contrast, samples from the uppermost unit seem to have interacted with aqueous fluid of near-surface origin, possibly at a temperature greater than $200^{\circ} \mathrm{C}$ (Boschi et al. 2003).

Summary diagrams designed to contrast the profile of the most heavily serpentinized peridotites in each of the three units are shown in Figure 8. Among the major elements, $\mathrm{Ca}$ is depleted in each case, a result of the breakdown of augite and of any interstitial plagioclase that may have been present. The breakdown of a calcic plagioclase would also cause a depletion in Al. Among the rare-earth elements, the same two minerals presumably were the main hosts, and their partial or complete removal led to loss of the rare earths. The serpentinized peridotites of the Uzal suite, perhaps subjected to a higher grade of eclogite-facies metamorphism, may have involved a greater proportion of a garnet-group mineral in the reactant assemblage, leading to mobilization of even the heavy REE.

The pattern of distribution of Li among samples allows us to reconstruct the possible environment of formation. Both the samples Ort-C and O-718, almost completely serpentinized ( $>95 \%$ by volume), are very depleted in $\mathrm{Li}(<0.5 \mathrm{ppm} \mathrm{Li})$, whereas sample Limo-1 ( $\sim 65 \%$ serpentine) contains six times as much. In general, the greater the proportion of serpentine, the lower the amount of $\mathrm{Li}$ and many other elements, including the REE. In light of the very low $\delta^{18} \mathrm{O}$ values of Ort-C and O-718, serpentinization may well reflect low-temperature hydrothermal metamorphism at a high $\mathrm{H}_{2} \mathrm{O}$ : rock ratio on the ocean floor (Zack et al. 2003).

Some of our samples show signs of enrichment in LREE, which can be explained by a metasomatic overprinting, as has been reported by Eggins et al. (1998) and Mével (2003). Leaching of some major and trace elements (including the REE) could take place during an ultimate serpentinization event due to meteoric water, bringing down the $\delta^{18} \mathrm{O}$ values as well. The observed correlation among elements can result from an external input from hydrothermal fluids circulating through distinct lithologies, like basalts or gabbros, enriched in these elements. Seawater should be precluded, as there would be an enrichment of $\mathrm{Sr}$ if that was the fluid involved (Wenner \& Taylor 1973), which is not the case for the most serpentinized samples (Ort-C and $\mathrm{O}-718)$. It seems that the maximum values of REE 


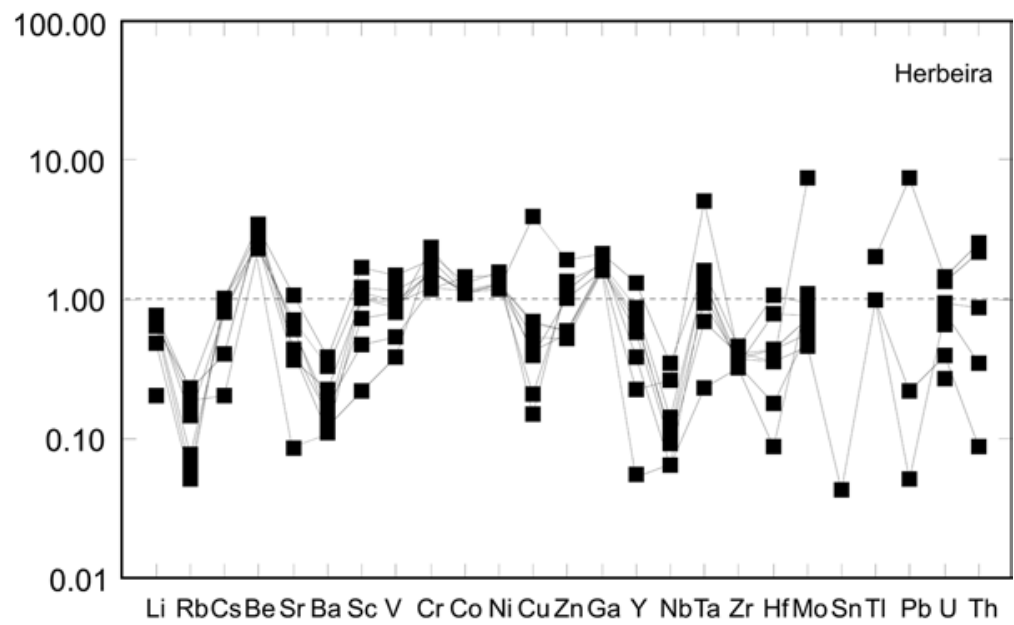

FIG. 5a. Normalization of trace-element concentrations of samples from Herbeira (Ort-\#) to the harzburgite of Santos et al. (2002).

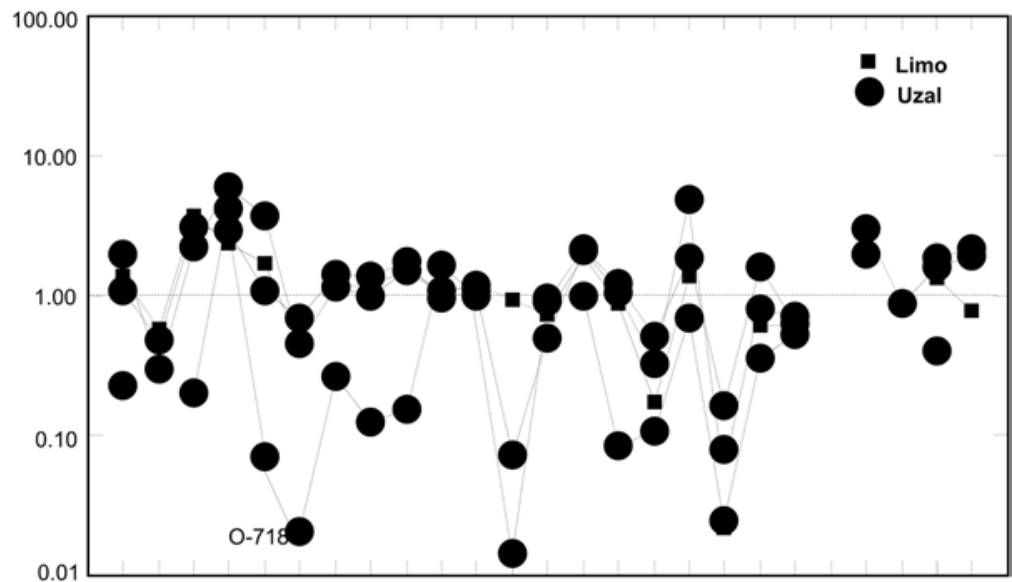

Li Rb Cs Be Sr Ba Sc V Cr Co Ni Cu Zn Ga Y Nb Ta Zr Hf Mo Sn TI Pb U Th

FIG. 5b. Normalization of trace-element concentrations of samples from Limo (Limo-1) and Uzal (O-\#) to the harzburgite of Santos et al. (2002).

could be related to the maximum values of $\delta^{18} \mathrm{O}$, that is, the samples that are related to igneous fluids. Most of Herbeira could represent serpentinization due to fluids enriched in $\mathrm{Cr}$, $\mathrm{Ni}$ and $\mathrm{Zn}$. Uzal represents a serpentinization fluid enriched in $\mathrm{Fe}, \mathrm{Mn}, \mathrm{Co}$ and $\mathrm{Zn}$.

Reduction in $\delta^{18} \mathrm{O}$ accompanying serpentinization of a peridotite suggests that a large quantity of surfacederived water interacted with it. An increase in $\delta^{18} \mathrm{O}$ values during the complete serpentinization suggests that a large quantity of other fluids affected these rocks as well (O'Hanley 1996). It is a question of origin of the fluid then, not the quantity of fluid involved. To Mével (2003), the $\delta^{18} \mathrm{O}$ values measured in serpentinites suggest that the fluid phase had a $\delta^{18} \mathrm{O}$ less than $5.5 \%$, consistent with dominant seawater as serpentinizing fluid. This could be the case for some of our samples, but the whole-rock geochemistry shows that a more complex history has contributed to the acquisition of different $\delta^{18} \mathrm{O}$ values in the same complex.

The samples described above as having the extreme values for the three different massifs of the Upper unit at Cabo Ortegal complex [Herbeira (Ort-C), Uzal 
(O-718) and Limo (Limo-1)] could be explained by differences in the environment of serpentinization in the three domains of ultramafic rocks that we have sampled (Fig. 1). Unlike the case of serpentinites on the modern seafloor, which have a monogenetic history, we have pointed out the existence of added complications in the case of the Cabo Ortegal lithospheric mantle, overthrust onto a continental crust as a result of the Variscan orogeny. It seems clear that the main complications involve the presence of sialic material, through which
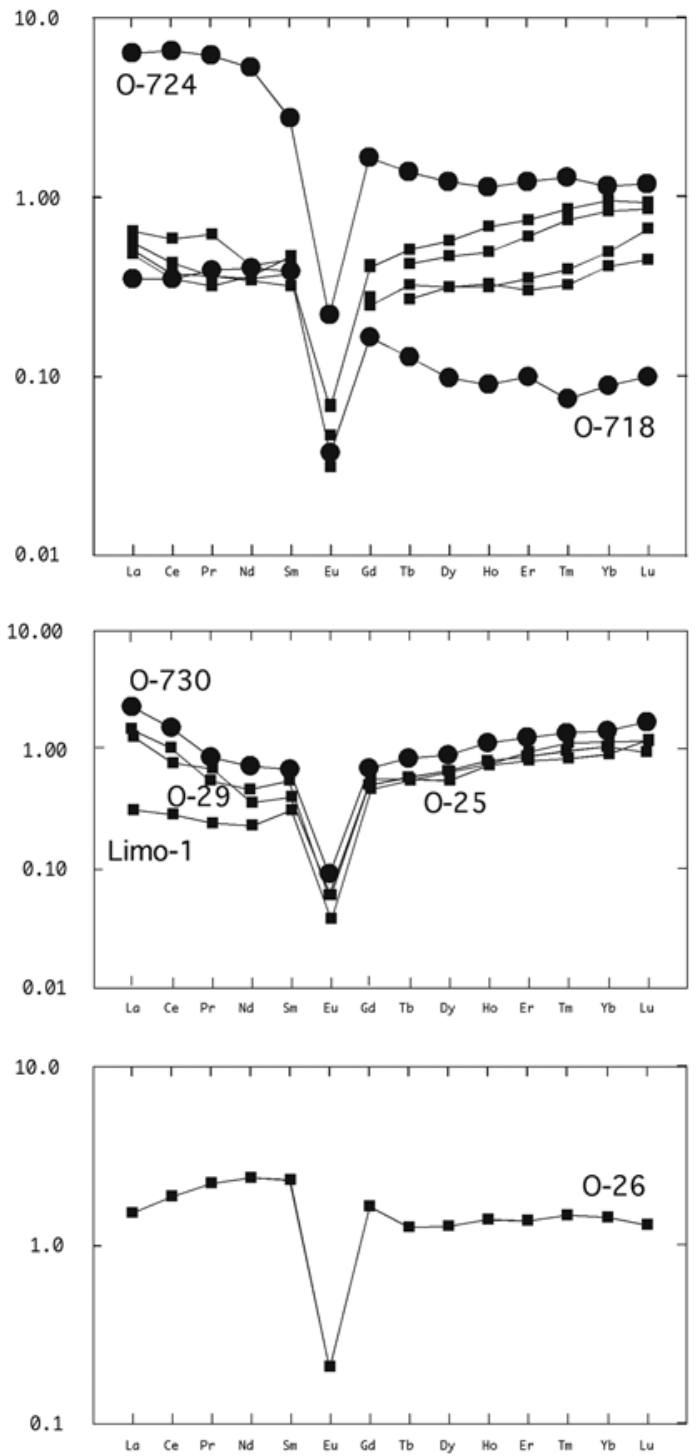

FIG. 5c. Normalization of REE concentrations of samples from Limo, Herbeira and Uzal to the harzburgite of Santos et al. (2002). the hydrothermal fluids could rise and from which they could leach incompatible and loosely held elements, including $\mathrm{Li}$ and the LREE.

Our whole-rock oxygen isotope data reveal a complex path in terms of provenance and rock units sampled; furthermore, as seen in Figure 2, there is clear evidence of a superposition of stages of serpentinization. Finally, there are the mineralogical variables with the lowermost thrust-slice Uzal, likely containing a stronger imprint of high-pressure, eclogite-facies metamorphism prior to the initiation of serpentinization. We contend that the Limo and Uzal thrust-slices show signs of interaction with fluids of igneous derivation, possibly related to calc-alkaline plutons generated in the subduction setting. In the Herbeira massif, being the uppermost thrust-slice, a final stage of serpentinization linked to meteoric water could well have obliterated the signature of previous changes and undoubtedly caused further leaching and mobilization.

It is appropriate to inquire whether there is any hope to find out more, and to sort out the events that have led to the observed mineralogy and geochemistry of the Cabo Ortegal serpentinites. We plan more thorough sampling, in particular of the Limo unit. We plan to acquire data on $\mathrm{B}, \mathrm{Cl}, \mathrm{Br}$ and $\mathrm{\delta D}$, and geochemical parameters using a microbeam technique, sampling the various mineralogical and textural domains within samples of serpentinite. Only with such information on selected representative samples will we be able to sort out the complications that we have brought to light.

\section{ACKNOWLEDGEMENTS}

This paper was supported by the projects BTE200304812, CGL2004-03048 and CGL2006-05128/BTE from the Spanish government. The authors thank A. Fallick for the analytical data and discussion on the stable isotopes. Drs. Fred J. Wicks, José F. Santos and Robert F. Martin helped to improve both the contents and the quality of the English in our manuscript.

\section{REFERENCES}

Boschi, C., FrüH-Green, G.L. \& Kelley, D.S. (2003): Links between tectonic and serpentinization processes and their consequences for hydrothermal activity (Atlantic massif, MAR $\left.30^{\circ} \mathrm{N}\right)$. Geophys. Res. Abstr. 5, 09796.

D'Antonio, M. \& Kristensen, M.B. (2004): Serpentine and brucite of ultramafic clasts from the South Chamorro Seamount (Ocean Drilling Program Leg 195, Site 1200): inferences for the serpentinization of the Mariana forearc mantle. Mineral. Mag. 68, 887-904.

Díaz García, F., Arenas, R., Martínez Catalán, J.R., GonZÁlez del TÁNAGo, J. \& DunNing, G.R. (1999): Tectonic evolution of the Careón ophiolite (northwest Spain): a remnant of oceanic lithosphere in the Variscan belt. $J$. Geol. 107, 587-605. 


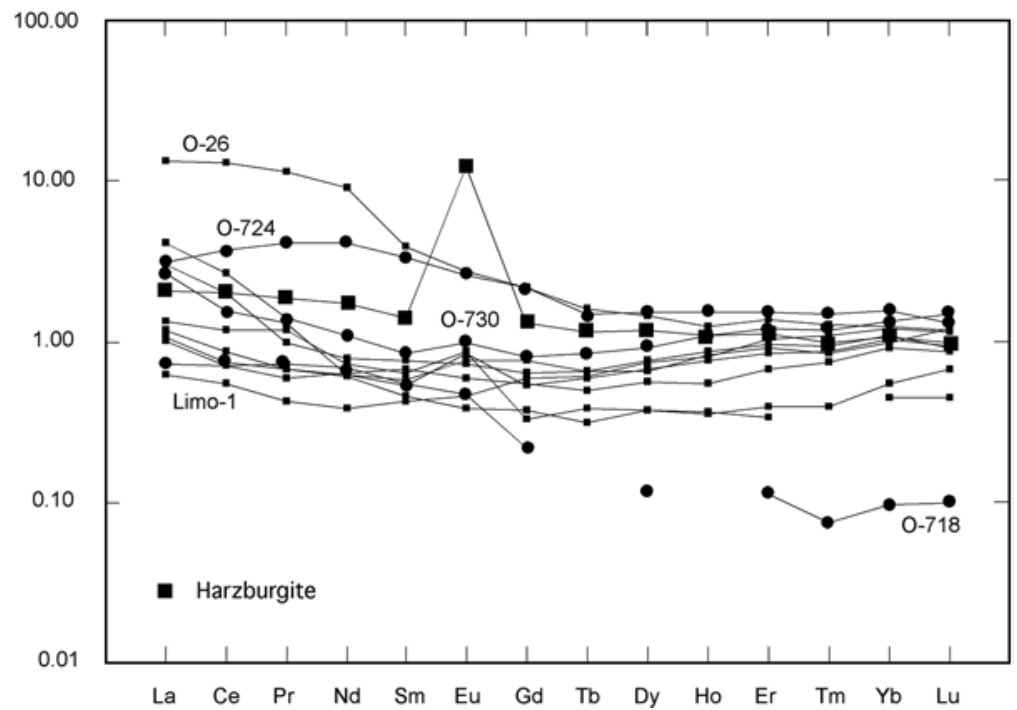

FIG. 6. Normalization of REE concentrations of samples from Limo, Herbeira and Uzal with respect to a chondritic composition.

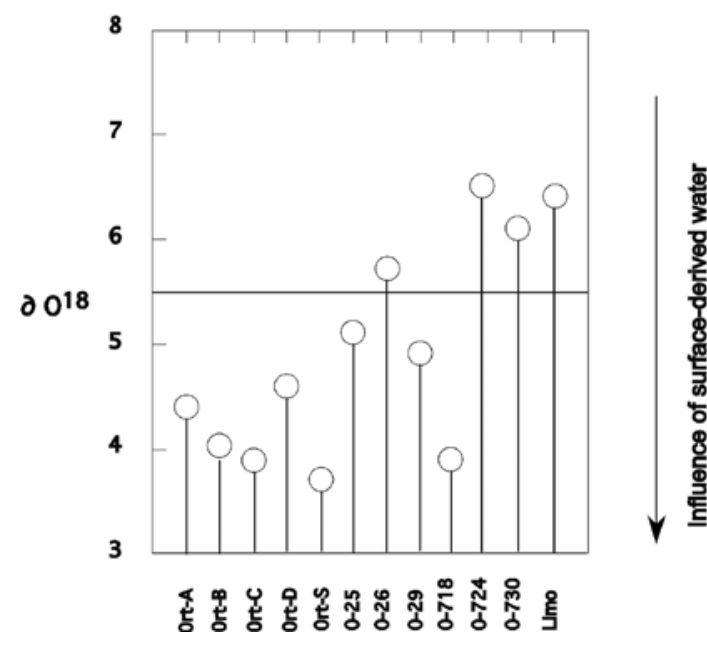

FIG. 7. Oxygen isotope values in samples. Values of $\delta^{18} \mathrm{O}$ range from 3.9 to $6.6 \%$. The value $5.5 \%$ is taken to be the threshold between high-temperature interaction with surface-derived fluids (below that value) and fluids of igneous origin (above that value) (Mével 2003).
EgGins, S.M., Rudnick, R.L. \& McDonough, W.F. (1998): The composition of peridotites and their minerals: a laser-ablation ICP-MS study. Earth Planet. Sci. Lett. 154, 53-71.

Gil Ibarguchi, J.I., Abalos, B., Azcárraga, J. \& Puelles, P. (1999): Deformation, high-pressure metamorphism and exhumation of ultramafic rocks in a deep subduction/collision setting (Cabo Ortegal, NW Spain). J. Metam. Geol. 17, 747-764.

Girardeau, J. \& Gil Ibarguchi, J. (1991): Pyroxenite-rich peridotites of the Cabo Ortegal complex (northwestern Spain): evidence for large-scale upper-mantle heterogeneity. J. Petrol., Special Issue on Lherzolites, 135-154.

Kyser, T.K., O'HANLEY, D.S. \& Wicks, F.J. (1999): The origin of fluids associated with serpentinization; evidence from stable-isotope compositions. Can. Mineral. 37, 223-237.

Mattielli, N., Weis, D., Grégoire, M., Mennessier, J.P., Cottin, J.Y. \& Giret, A. (1996): Kerguelen basic and ultrabasic xenoliths: evidence for long-lived Kerguelen hotspot activity. Lithos 37, 261-280.

MÉvel, C. (2003): Serpentinization of abyssal peridotites at mid-ocean ridges. C.R. Geosciences 335, 825-852.

Miyashiro, A., Shido, F. \& Ewing, M. (1969): Composition and origin of serpentinites from the Mid-Atlantic Ridge near $24^{\circ}$ and $30^{\circ}$ north latitude. Contrib. Mineral. Petrol. 23, 117-127. 
TABLE 3. CONCENTRATION OF THE RARE-EARTH ELEMENTS IN THE PERIDOTITE SAMPLES, CABO ORTEGAL COMPLEX

\begin{tabular}{|c|c|c|c|c|c|c|c|c|c|c|c|c|c|c|c|c|c|}
\hline & $\mathrm{La}$ & $\mathrm{Ce}$ & Pr & $\mathrm{Nd}$ & $\mathrm{Sm}$ & Eu & $\mathrm{Gd}$ & $\mathrm{Tb}$ & Dy & $\mathrm{Ho}_{\mathrm{O}}$ & $\mathrm{Er}$ & $T m$ & $Y b$ & Lu & $\Sigma R E E$ & La/Lu & $\mathrm{Eu}^{*}$ \\
\hline ORT-A & 0.38 & 0.69 & 0.08 & 0.45 & 0.16 & 0.05 & 0.17 & 0.03 & 0.21 & 0.05 & 0.17 & 0.03 & 0.23 & 0.04 & 2.74 & 1.16 & 0.95 \\
\hline ORT-B & 0.4 & 0.72 & 0.10 & 0.44 & 0.13 & 0.08 & 0.17 & 0.04 & 0.26 & 0.07 & 0.21 & 0.04 & 0.26 & 0.04 & 2.93 & 1.13 & 1.56 \\
\hline ORT-C & 0.02 & b.d.l. & 0.01 & 0.20 & 0.04 & 0.02 & 0.02 & b.d.l. & b.d.l. & 0.01 & 0.02 & b.d.l. & 0.05 & 0.01 & 0.35 & 2.0 & \\
\hline ORT-D & 0.44 & 0.83 & 0.10 & 0.43 & 0.11 & 0.04 & 0.12 & 0.02 & 0.14 & 0.03 & 0.10 & 0.02 & 0.14 & 0.03 & 2.52 & 1.75 & 0.94 \\
\hline ORT-S & 0.5 & 1.14 & 0.16 & 0.52 & 0.15 & 0.08 & 0.10 & 0.02 & 0.14 & 0.03 & 0.09 & 0.01 & 0.11 & 0.02 & 3.07 & 3.02 & 1.8 \\
\hline 0.25 & 0.99 & 1.50 & 0.18 & 0.45 & 0.13 & 0.07 & 0.24 & 0.04 & 0.25 & 0.08 & 0.23 & 0.03 & 0.25 & 0.05 & 4.49 & 2.19 & 1.15 \\
\hline $0-26$ & 1.17 & 3.63 & 0.58 & 2.97 & 0.77 & 0.24 & 0.68 & 0.09 & 0.58 & 0.14 & 0.39 & 0.06 & 0.39 & 0.05 & 11.73 & 2.43 & 0.95 \\
\hline $0-29$ & 1.12 & 1.93 & 0.14 & 0.56 & 0.18 & 0.07 & 0.20 & 0.04 & 0.29 & 0.08 & 0.24 & 0.04 & 0.28 & 0.04 & 5.19 & 3.27 & 1.04 \\
\hline 0.724 & 4.93 & 12.59 & 1.61 & 6.53 & 0.92 & 0.25 & 0.68 & 0.10 & 0.55 & 0.11 & 0.34 & 0.05 & 0.31 & 0.05 & 1.89 & 7.27 & 1.2 \\
\hline 0.730 & 1.52 & 2.59 & 0.20 & 0.79 & 0.20 & 0.09 & 0.25 & 0.05 & 0.35 & 0.10 & 0.31 & 0.05 & 0.34 & 0.06 & 29.01 & 11.35 & 0.89 \\
\hline $0-718$ & 0.27 & 0.68 & 0.10 & 0.50 & 0.13 & 0.04 & 0.07 & 0.01 & 0.04 & 0.01 & 0.03 & b.d.l. & 0.02 & b.d.l. & 6.87 & 2.48 & 1.19 \\
\hline Limo-1 & 0.23 & 0.53 & 0.06 & 0.28 & 0.10 & 0.04 & 0.19 & 0.04 & 0.28 & 0.07 & 0.26 & 0.04 & 0.30 & 0.05 & 2.47 & 0.55 & 0.89 \\
\hline Harzb-1 & 0.77 & 1.93 & 0.26 & 1.24 & 0.33 & 1.13 & 0.41 & 0.07 & 0.45 & 0.10 & 0.28 & 0.04 & 0.27 & 0.04 & 24.50 & 19.25 & 1.08 \\
\hline
\end{tabular}

b.d.l.: below detection limit. Harzb-1 is a sample of harzburgite from Santos et al. (2002). Results are quoted in ppm. Analyses were obtained by ICP-MS at the Universidad de Granada.

\begin{tabular}{|c|c|c|c|}
\hline Reference & $\begin{array}{c}\text { Mean and } \\
\text { standard } \\
\text { deviation }(\% 0)\end{array}$ & Reference & $\begin{array}{c}\text { Mean and } \\
\text { standard } \\
\text { deviation }(\% 0)\end{array}$ \\
\hline Ort-A & $4.4 \pm 0.1(n=2)$ & Ort-26 & $5.7 \pm 0.3(n=4)$ \\
\hline Ort-B & $4.0 \pm 0.1(n=2)$ & Ort-29 & $4.9 \pm 0.3(n=3)$ \\
\hline Ort-C & $3.9+0.3(n=2)$ & 0.718 & $3.9 \pm 0.7(n=2)$ \\
\hline Ort-D & $4.6 \pm 0.2(n=4)$ & 0.724 & $6.5 \pm 0.9(n=2)$ \\
\hline Ort-S & $6.6 \pm 0.3(n=2)$ & 0.730 & $6.1 \pm 0.2(n=2)$ \\
\hline Ort-25 & $5.1 \pm 0.2(n=4)$ & Limo-1 & $6.4 \pm 0.2(n=4)$ \\
\hline Peridotite & Serpentinite & $0-12^{*}$ & Seawater \\
\hline
\end{tabular}

$\mathrm{n}$ : number of samples analyzed. * Mével (2003).

Moody, J.B. (1976): Serpentinization: a review. Lithos 9 , 125-138.

Moreno, T., Gibbons, W., Prichard, H.M. \& Lunar, R. (2001): Platiniferous chromitite and the tectonic setting of ultramafic rocks in Cabo Ortegal, NW Spain. J. Geol. Soc. London 158, 601-614.

O'Hanley, D.S. (1996): Serpentinites, Records of Tectonic and Petrological History. Oxford University Press, New York, N.Y.

Pereira, M.D., Shaw, D.M. \& Acosta, A. (2003): Mobile trace elements and fluid-dominated processes in the Ronda peridotite, southern Spain. Can. Mineral. 41, 617-625.

Pereira, M.D., Yenes, M., Blanco, J.A. \& Peinado, M. (2007): Characterization of serpentinites to define their appropriate use as dimension stone. Geol. Soc., Spec. Publ. 271, 55-62.
Peucat, J.J., Bernard-Griffithes, J., Gil Ibarguchi, J.I., DALlMEYer, R.D., MENOt, R.P., CORNICHET, J. \& Iglesias PonCE De LeÓn, M. (1990): Geochemical and geochronological cross section of the deep Variscan crust: the Cabo Ortegal high-pressure nappe (northwestern Spain). Tectonophysics 177, 263-292.

Santos, J.F., Schärer, U., Gil Ibarguchi, J.I. \& Girardeau, J. (2002): Genesis of pyroxenite-rich peridotite at Cabo Ortegal (NW Spain): geochemical an $\mathrm{Pb}-\mathrm{Sr}-\mathrm{Nd}$ isotope data. J. Petrol. 43, 17-43.

Santos Zalduegui, J.F., Schärer, U., Gil Ibarguchi, I. \& GirardeAu, J.J. (1996): Origin and evolution of the Paleozoic Cabo Ortegal ultramafic-mafic complex (NW Spain): $\mathrm{U}-\mathrm{Pb}, \mathrm{Rb}-\mathrm{Sr}$ and $\mathrm{Pb}-\mathrm{Pb}$ isotope data. Chem. Geol. 129, 281-304.

SEYFRIED, W.E. \& DibBLE, W.E. (1980): Seawater-peridotite interaction at $300^{\circ} \mathrm{C}$ and 500 bars: implications for the origin of oceanic serpentinites. Geochim. Cosmochim. Acta 44, 309-321.

SHARP, Z.D. (1990): A laser-based microanalytical method for the in-situ determination of oxygen isotope ratios in silicates and oxides. Geochim. Cosmochim. Acta 54, 1353-1357.

TAYLOR, S.R. \& McLennan, S.M. (1985): The Continental Crust: its Composition and Evolution. Blackwell, Oxford, U.K.

Vogel, D.E. (1967): Petrology of eclogite and pyrigarnitebearing polymetamorphic rock complex at Cabo Ortegal, NW Spain. Leidse Geol. Mededel. 40, 121-213. 

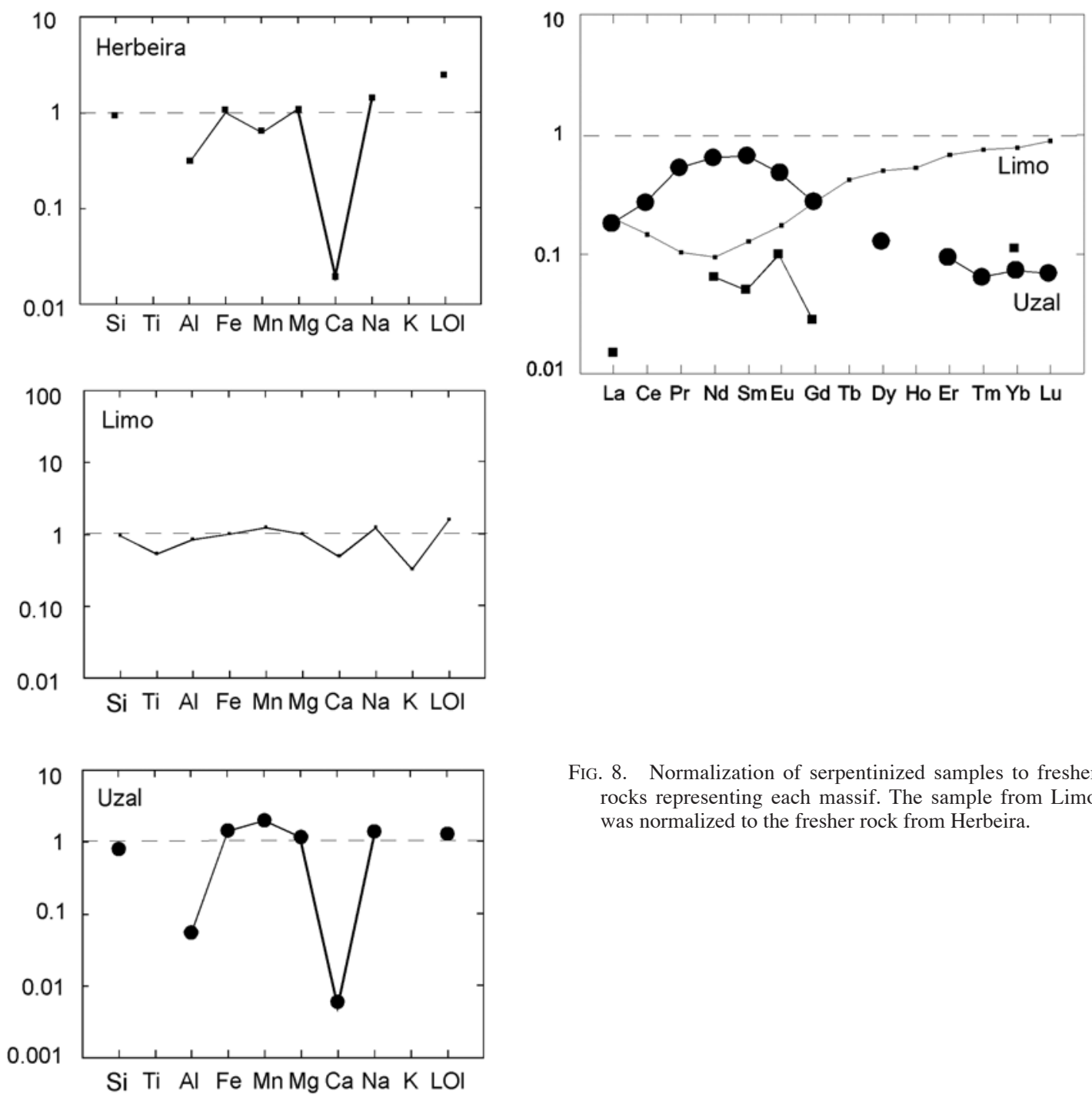

FIG. 8. Normalization of serpentinized samples to fresher rocks representing each massif. The sample from Limo was normalized to the fresher rock from Herbeira.

WENNER, D.B. \& TAYLOR, H.P., JR. (1973): Oxygen and hydrogen isotope studies of the serpentinization of ultramafic rocks in oceanic environments and ophiolite complexes. Am. J. Sci. 273, 207-239.

Wicks, F.J. \& WhitTAKeR, E.J.W. (1977): Serpentine textures and serpentinization. Can. Mineral. 15, 459-488.
Zack, T., Tomaseck, P.B., Rudnick, R.L., Dalpé, C. \& McDonough, W.F. (2003): Extremely light Li in orogenic eclogites: the role of isotope fractionation during dehydration in subducted oceanic crust. Earth Planet. Sci. Lett. 208, 279-290.

Received May 8, 2006, revised manuscript accepted January 5, 2008. 
